\title{
HISTOPATHOLOGICAL SPECTRUM OF HYPERPIGMENTED LESIONS OF SKIN
}

\author{
Shushan Shweta Jayker1, Jyothi Anantharaj'2, Sharmila Prakash Surhonne3, Ramya Ramachandra4, Radhika Yajaman Gurumurthy5 \\ ${ }_{1}^{1}$ Assistant Professor, Department of Pathology, Rajarajeswari Medical College and Hospital, Kambipura, Mysore Road, Bangalore. \\ 2 Professor, Department of Pathology, Rajarajeswari Medical College and Hospital, Kambipura, Mysore Road, Bangalore. \\ 3 Professor, Department of Pathology, Rajarajeswari Medical College and Hospital, Kambipura, Mysore Road, Bangalore. \\ ${ }^{4}$ Tutor, Department of Pathology, Rajarajeswari Medical College and Hospital, Kambipura, Mysore Road, Bangalore. \\ 5Tutor, Department of Pathology, Rajarajeswari Medical College and Hospital, Kambipura, Mysore Road, Bangalore.
}

\section{ABSTRACT}

\section{BACKGROUND}

Hyperpigmentation of skin is one of the commonest cosmetic skin complaint encountered in Dermatology Outpatient Clinic. Evidence for a correct diagnosis may be lacking without histopathologic examination of skin biopsies.

\section{METHODS}

A total of 85 cases of histologically diagnosed hyperpigmented lesions were included. Clinical features like age, sex, type of pigmentation, location were recorded. Histological features of these were studied.

\section{RESULTS}

Out of 85 cases, majority (12.94\%) were classical lichen planus. Most of cases were in the age group of 21-30 years and showed female preponderance with extremities as most common site of distribution.

\section{CONCLUSION}

In our study, hyperpigmented skin lesions were most common in females with lichen planus as the most common diagnosis. Histopathology is a dependable tool in identifying and differentiating these lesions.

\section{KEYWORDS}

Hyperpigmentation, Histopathology, Lichen Planus.

HOW TO CITE THIS ARTICLE: Jayker SS, Anantharaj J, Surhonne SP, et al. Histopathological spectrum of hyperpigmented lesions of skin. J. Evolution Med. Dent. Sci. 2016;5(34):1913-1916, DOI: 10.14260/jemds/2016/453

\section{INTRODUCTION}

Hyperpigmentary skin disorders may be defined as increased pigmentation of the skin and/or mucus membranes. ${ }^{1}$ Hyperpigmentation may be caused by abnormality in epidermis or dermis. Hyperpigmentary skin disorders may be broadly classified into two groups, epidermal which is characterized by 'Brown hyperpigmentation' and dermal which is known as 'blue hyperpigmentation' or 'Ceruloderma. ${ }^{\text {' }}$

Pigmented skin lesions comprise a large component of most histopathologists' workload, and although there is a wide spectrum of histological appearances most can be reported as simple benign naevi. ${ }^{2}$

Histopathological examination revealed epidermal pigmentation as the commonest finding followed by dermal pigmentation with or without hyperkeratosis. The histology based treatment principles may be helpful for establishing a standardized treatment algorithm for hyperpigmented skin lesions.3,4 Disorders of pigmentation can result from migration abnormalities of melanocytes from neural crest to the skin during embryogenesis, impairment of melanosome transfer to

Financial or Other, Competing Interest: None.

Submission 10-03-2016, Peer Review 06-04-2016,

Acceptance 12-04-2016, Published 28-04-2016.

Corresponding Author:

Dr. Shushan Shweta Jayker,

Assistant Professor,

Department of Pathology,

Rajarajeswari Medical College and Hospital,

Kambipura, Mysore Road,

Bangalore-560024.

E-mail: shwetajayker@gmail.com

DOI: $10.14260 /$ jemds/2016/453 keratinocytes and alteration in melanin synthesis.5,6 Hyperpigmentation is not just a cosmetic deformity causing psychological upset due to disfigurement, but can also reflect underlying organ dysfunction. ${ }^{7,8}$

\section{OBJECTIVES OF THE STUDY}

1. To know the clinical and histopathological patterns of hyperpigmented lesions of skin.

2. To determine the age and sex distribution in various hyperpigmented skin diseases.

\section{MATERIALS AND METHODS}

Data for the retrospective study was obtained from skin biopsies of hyperpigmented skin lesions received in the Department of Pathology, RRMCH, over a period of three years from May 2010 to May 2013.

Details of patients with hyperpigmented skin lesions were retrieved from the archives of the Department of Pathology. The slides were reviewed and analysed. Histopathological findings were correlated with clinical features.

Histological examination of skin biopsy is done on $\mathrm{H}$ and E stain. Detailed histopathological examination of the samples were conducted and correlated with clinical findings and compared with the available literature.

\section{Inclusion Criteria}

Skin biopsies of all non-neoplastic and neoplastic hyperpigmented skin lesions of all age groups and both sexes were included. 


\section{Exclusion Criteria}

Skin biopsies other than hyperpigmented skin lesions and inadequate biopsy specimen were excluded from the study.

\section{RESULTS}

\begin{tabular}{|c|c|c|c|}
\hline $\begin{array}{l}\text { Sl. } \\
\text { No. }\end{array}$ & Lesions & $\begin{array}{l}\text { No. of } \\
\text { Cases }\end{array}$ & $\begin{array}{c}\text { Percentage } \\
\%\end{array}$ \\
\hline 1 & Lichen planus & 11 & 12.94 \\
\hline 2 & $\begin{array}{l}\text { Lichen planus } \\
\text { pigmentosus }\end{array}$ & 06 & 7.05 \\
\hline 3 & Psoriasis & 05 & 5.88 \\
\hline 4 & Prurigo nodularis & 05 & 5.88 \\
\hline 5 & Morphea & 04 & 4.70 \\
\hline 6 & Non-specific dermatitis & 04 & 4.70 \\
\hline 7 & $\begin{array}{l}\text { Lichen simplex } \\
\text { chronicus }\end{array}$ & 04 & 4.70 \\
\hline 8 & Lichen striatus & 03 & 3.52 \\
\hline 9 & Verruca plana & 03 & 3.52 \\
\hline 10 & Becker naevus & 03 & 3.52 \\
\hline 11 & Pemphigus foliaceus & 02 & 2.35 \\
\hline 12 & Macular amyloidosis & 02 & 2.35 \\
\hline 13 & Linear epidermal nevus & 02 & 2.35 \\
\hline 14 & Lentigo simplex & 02 & 2.35 \\
\hline 15 & $\begin{array}{l}\text { Lichen sclerosus et } \\
\text { atrophicus (LSEA) }\end{array}$ & 02 & 2.35 \\
\hline 16 & Lichen amyloidosis & 01 & 1.17 \\
\hline 17 & Junctional nevus & 01 & 1.17 \\
\hline 18 & Panniculitis & 01 & 1.17 \\
\hline 19 & Nevus comedonicus & 01 & 1.17 \\
\hline 20 & Dermatitis herpetiformis & 01 & 1.17 \\
\hline 21 & Fixed drug eruption & 01 & 1.17 \\
\hline 22 & Lichen planopilaris & 01 & 1.17 \\
\hline 23 & Syringoma & 01 & 1.17 \\
\hline 24 & $\begin{array}{l}\text { Systemic lupus } \\
\text { erythematosus }\end{array}$ & 01 & 1.17 \\
\hline 25 & Keratosis pilaris & 01 & 1.17 \\
\hline 26 & $\begin{array}{c}\text { Papulonecrotic } \\
\text { tuberculid }\end{array}$ & 01 & 1.17 \\
\hline 27 & $\begin{array}{l}\text { Pityriasis lichenoides } \\
\text { chronica }\end{array}$ & 01 & 1.17 \\
\hline 28 & Porokeratosis & 01 & 1.17 \\
\hline 29 & $\begin{array}{l}\text { Discoid lupus } \\
\text { erythematosus }\end{array}$ & 01 & 1.17 \\
\hline 30 & $\begin{array}{l}\text { Epidermodysplasia } \\
\text { verruciformis }\end{array}$ & 01 & 1.17 \\
\hline 31 & Ichthyosis vulgaris & 01 & 1.17 \\
\hline 32 & $\begin{array}{l}\text { Erythema dyschromicum } \\
\text { perstans }\end{array}$ & 01 & 1.17 \\
\hline 33 & Erythema nodosum & 01 & 1.17 \\
\hline 34 & Lichen planus atrophicus & 01 & 1.17 \\
\hline 35 & Kyrle disease & 01 & 1.17 \\
\hline 36 & Seborrheic keratosis & 01 & 1.17 \\
\hline 37 & Parapsoriasis & 01 & 1.17 \\
\hline 38 & Lichen planus actinicus & 01 & 1.17 \\
\hline 39 & $\begin{array}{l}\text { Post inflammatory } \\
\text { hyperpigmentation }\end{array}$ & 01 & 1.17 \\
\hline 40 & $\begin{array}{l}\text { Large plaque } \\
\text { parapsoriasis }\end{array}$ & 01 & 1.17 \\
\hline 41 & Darier's disease & 01 & 1.17 \\
\hline 42 & $\begin{array}{l}\text { Pigmentary demarcation } \\
\text { lines }\end{array}$ & 01 & 1.17 \\
\hline 43 & Chronic folliculitis & 01 & 1.17 \\
\hline \multicolumn{4}{|c|}{ Table 1: Distribution of Case } \\
\hline
\end{tabular}

\begin{tabular}{|c|c|c|}
\hline Correlation & $\begin{array}{c}\text { No. of } \\
\text { Cases }\end{array}$ & $\begin{array}{c}\text { Percentage } \\
\%\end{array}$ \\
\hline $\begin{array}{c}\text { Histopathology confirmed } \\
\text { diagnosis }\end{array}$ & 67 & $78.9 \%$ \\
\hline $\begin{array}{c}\text { Diagnosed only on } \\
\text { histopathology }\end{array}$ & 18 & $21.1 \%$ \\
\hline \multicolumn{2}{|c|}{ Table 2: Clinical and Histopathology Correlation } \\
\hline
\end{tabular}

\begin{tabular}{|c|c|c|c|c|}
\hline $\begin{array}{l}\text { Sl. } \\
\text { No. }\end{array}$ & Epidermis & $\begin{array}{c}\text { Cases } \\
n=85 \\
(\%)\end{array}$ & Dermis & $\begin{array}{c}\text { Cases } \\
n=85 \\
(\%)\end{array}$ \\
\hline 1 & $\begin{array}{l}\text { Hyper- } \\
\text { keratosis }\end{array}$ & $\begin{array}{c}54 \\
(63.6 \%)\end{array}$ & $\begin{array}{l}\text { Perivas- } \\
\text { cular } \\
\text { lympho- } \\
\text { cytic } \\
\text { infiltrate }\end{array}$ & $\begin{array}{c}34 \\
(40 \%)\end{array}$ \\
\hline 2 & Parakeratosis & $\begin{array}{c}20 \\
(23.6 \%)\end{array}$ & $\begin{array}{l}\text { Periadnexal } \\
\text { lymphocyti } \\
\text { c infiltrate }\end{array}$ & $\begin{array}{c}09 \\
(10.6 \%)\end{array}$ \\
\hline 3 & Acanthosis & $\begin{array}{c}42 \\
(49.5 \%) \\
\end{array}$ & $\begin{array}{l}\text { Band like } \\
\text { infiltrate }\end{array}$ & $\begin{array}{c}11 \\
(13 \%) \\
\end{array}$ \\
\hline 4 & Atrophy & $\begin{array}{c}14 \\
(16.5 \%)\end{array}$ & $\begin{array}{l}\text { Pigment in- } \\
\text { continence }\end{array}$ & $\begin{array}{c}26 \\
(30.6 \%)\end{array}$ \\
\hline 5 & $\begin{array}{l}\text { Hyper- } \\
\text { granulosis }\end{array}$ & $\begin{array}{c}13 \\
(15.3 \%)\end{array}$ & $\begin{array}{l}\text { Mono- } \\
\text { nuclear } \\
\text { cells }\end{array}$ & $\begin{array}{c}66 \\
(77.7 \%)\end{array}$ \\
\hline 6 & Spongiosis & $\begin{array}{c}03 \\
(3.6 \%)\end{array}$ & Plasma cells & $\begin{array}{c}11 \\
(13 \%)\end{array}$ \\
\hline 7 & Exocytosis & $\begin{array}{c}02 \\
(2.4 \%)\end{array}$ & Eosinophils & $\begin{array}{c}05 \\
(5.9 \%)\end{array}$ \\
\hline 8 & $\begin{array}{l}\text { Follicular } \\
\text { plugging }\end{array}$ & $\begin{array}{c}12 \\
(14.2 \%) \\
\end{array}$ & Neutrophils & $\begin{array}{c}09 \\
(10.6 \%) \\
\end{array}$ \\
\hline 9 & $\begin{array}{c}\text { Basal cell } \\
\text { degeneration }\end{array}$ & $\begin{array}{c}26 \\
(30.6 \%)\end{array}$ & & \\
\hline 10 & $\begin{array}{l}\text { Hyperpigmen } \\
\text { tation of } \\
\text { basal layer }\end{array}$ & $\begin{array}{c}15 \\
(17.7 \%)\end{array}$ & & \\
\hline \multicolumn{5}{|c|}{$\begin{array}{l}\text { Table 3: Spectrum of Histopathological } \\
\text { Changes in Epidermis and Dermis }\end{array}$} \\
\hline
\end{tabular}

Of the 85 patients, 47 were females and 38 were males. The youngest was an 8-year-old female and the oldest was an 80-year-old male. Females were affected more commonly than males. The maximum number of cases occurred in middle age group of 21 to 30 years. The most common site of distribution of hyperpigmented skin lesions are extremities, that are upper and lower limbs. Other sites include back, face, neck, chest, abdomen and all over the body with multiple sites involvement in most of the cases. Most of the cases showed increased epidermal pigmentation and only one lesion presented with dermal hyperpigmentation that is erythema dyschromicum perstans (Figure 1) in non-neoplastic lesions.

On histopathological examination of 85 cases, 11 were classical Lichen planus and 09 were its morphological variants (Figure 2); 5 cases of Psoriasis, 5 cases of Prurigo nodularis, 4 cases of Morphea (Figure 3), 4 cases of Lichen simplex chronicus, 3 cases of Lichen striatus, 3 cases of Verruca plana, 3 cases of Becker nevus, 2 cases of Pemphigus foliaceus, 2 cases of Linear epidermal nevus (Figure 4), 2 cases of Macular amyloidosis, 2 cases of Lentigo simplex, 2 cases of LSEA and one case each of other lesions as shown in Table 1.

During this study period 85 cases were clinically presented as hyperpigmented lesions, of which 67 (78.9\%) 
cases were confirmed on histopathology and 18 (21.1\%) cases were diagnosed only on histopathology (Table 2).

Spectrum of histopathological changes in epidermis and dermis were also studied (Table 3). On histopathological examination, epidermal changes like hyperkeratosis, acanthosis, basal cell degeneration and dermal changes like perivascular and interstitial mononuclear infiltrate and pigment incontinence were seen in most of the patients.

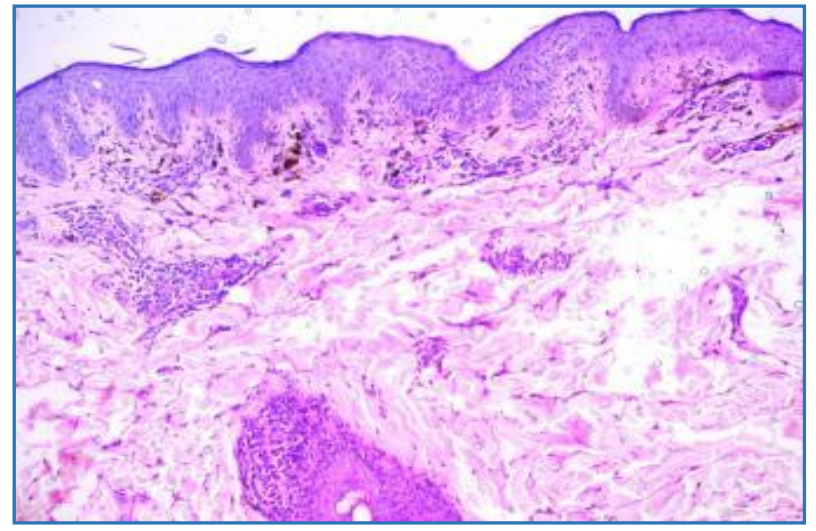

Fig. 1: Erythema Dyschromicum Perstans (H\&E 20X) showing Basal Cell Degeneration with Pigment Incontinence in Upper Dermis and Perivascular Lymphohistiocytic Infiltrate with Melanophages

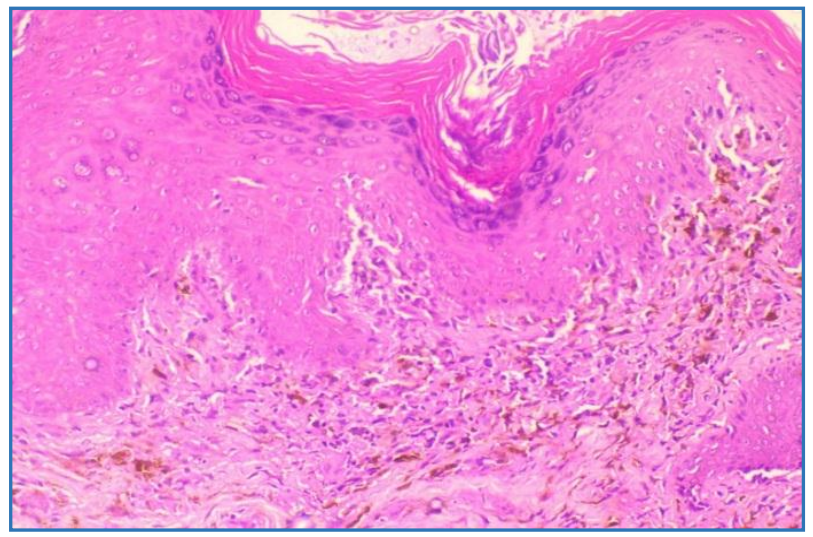

Fig. 2: Lichen Planus Pigmentosus (H\&E 20X) shows Basal Cell Vacuolation, Pigment Incontinence with Dense Band Like Mononuclear Infiltrate in the Upper Dermis

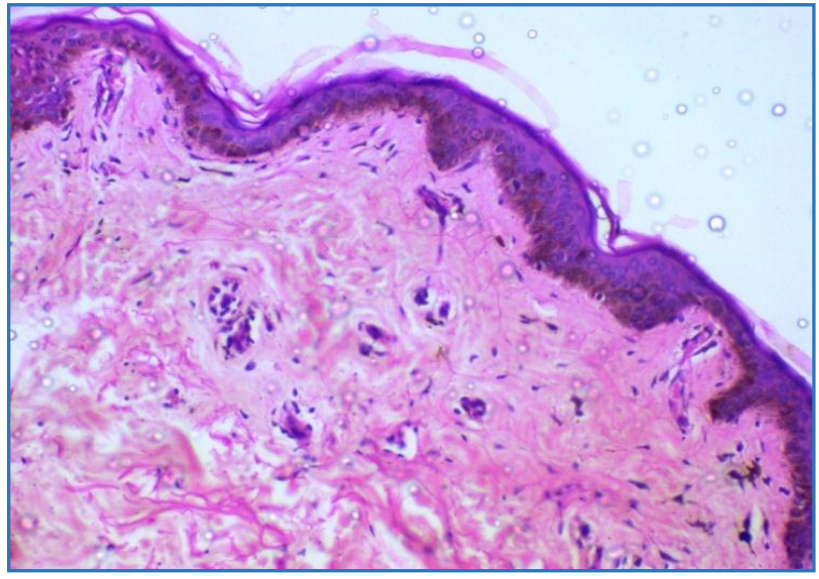

Fig. 3: Morphea (H\&E 20X) showing Focal Thinning of Epidermis, Increased Basal Melanocytes, Thickened Reticular Dermis with Increased Collagen and Atrophic Adnexae

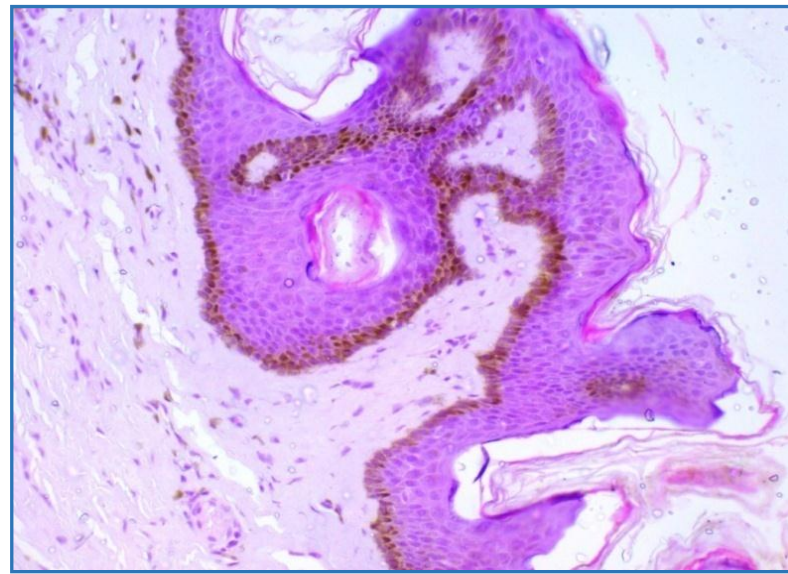

Fig. 4: Linear Epidermal Nevus (H\&E 20X) showing Papillomatosis, Hyperkeratosis Acanthosis and Increased Number of Melanocytes along the Basal Layer

\section{DISCUSSION}

In our study, we observed that classical lichen planus was most common constituting $12.94 \%$ of total cases followed by lichen planus pigmentosus (7.05\%). A similar dominance of classical lichen planus over other variants were observed by other authors (Priyadarshini D, et al). ${ }^{9}$

The maximum number of patients were seen in the age group of 21-30 yrs. The youngest was an 8- year-old female and oldest was an 80-year-old male. In our study of the 85 patients, 38 were males and 47 females with a male/female ratio of 0.80 , which was in concordance with the findings of study by Mahesh Kumar U et al.10

Lichen planus is an idiopathic subacute or chronic inflammatory disease of skin, mucous membranes and nails. Exact pathogenesis of lichen planus is still unclear. Cutaneous lichen planus is characterized by polygonal, flat-topped, violaceous papules and plaques. The lesions may result in long standing hyperpigmentation, especially in dark skinned patients. Lichen planus has characteristic histopathological features, which make the diagnosis relatively easy. ${ }^{11}$ Lichen Planus Pigmentosus (LPP) is a macular variant of Lichen planus reported most commonly from the Indian subcontinent and the Middle-East. The histopathology of LPP is in general subtle with sparse inflammation, requiring thorough evaluation of the biopsy. Therefore, diagnosis of these is based on clinicopathological correlation. ${ }^{12}$

It is essential to distinguish Lichen planus from other lesions on microscopy, as they have got different treatment modalities and prognosis too differs.

\section{CONCLUSION}

To summarize, Lichen planus and its variants were the most common hyperpigmented skin lesions encountered in our study. Most of the lesions were of epidermal type and only one dermal type of hyperpigmentation was noted. It is important to distinguish between epidermal and dermal hyperpigmented lesions; because epidermal pigmentation responds better to treatment than dermal pigmentation which is resistant to treatment. The differential diagnosis can be narrowed down by focusing on the key histopathological features of various lesions. Specific diagnosis of hyperpigmented lesions is based on possible histopathologic findings and interpretation in context of its clinical presentation. 


\section{REFERENCES}

1. Dutta AK, Datta PK, Dhar S. Hyperpigmentary disorders. In: Valia RG, Valia AR, eds. IADVL textbook and atlas of dermatology. Mumbai: Bhalani $2^{\text {nd }}$ edn, 2003;1:760-98.

2. Edwards SL, Blessing K. Problematic pigmented lesions: approach to diagnosis. J Clin Pathol 2000;53:409-18.

3. Kurita M, Kato H, Yoshimura K. A therapeutic strategy based on histological assessment of hyperpigmented skin lesions in Asians. Journal of Plastic, Reconstructive and Aesthetic Surgery 2009;62(7):955-63.

4. Costin EG, Hearing JV. Human skin pigmentation: melanocytes modulate skin color in response to stress. The FASEB Journal 2007;21(4):976-94.

5. Valia RG. Pigmentary Disorders. In: IADVL textbook of dermatology. Edited by Valia RA: Bhalani publishers Mumbai 3rd edn, 2008;1:760-90.

6. Stulberg DL, Clark N, Daniel Tovey, et al. Common hyperpigmentation disorder in adults: part II. Melanoma, seborrheic keratosis, acanthosis nigricans, melasma, diabetic dermopathy, tinea versicolor and postinflammatory hyperpigmentation. Journal of American academy of family physicians 2003;68(10):1963-9.
7. Shenoi SD, Rao R. Pigmented contact dermatitis. Indian Journal of Dermatol venereol Leprol 2007;73(5):285-7.

8. Masakazu K, Harunosuke K, Yoshimura K. A therapeutic strategy based on histological assessment of hyperpigmented skin lesions in Asians. Journal of Plastic Reconstructive \& Aesthetic Surgery 2008;62(7):955-63.

9. Priyadarshini D, Jeyachandran P. Histopathological and clinical correlation of hyperpigmented skin lesions. International J Scient Research 2014;3(3):1-3.

10. Mahesh Kumar U, Yelikar RB, Inamdar CA, et al. A clinicopathological study of lichenoid tissue reactions-a tertiary care experience. Journal of Clinical and Diagnostic Research 2013;7(2):312-6.

11. Parihar A, Sharma S, Bhattacharya NS, et al. A clinicopathological study of cutaneous lichen planus. Journal of Dermatology \& Dermatologic surgery 2015;19(1):21-6.

12. Khanna N, Rasool S. Facia melanosis: Indian perspective. Indian J Dermatol Venereol Leprol 2011;77(5):552-64. 